\title{
Prevalence and hospitalization rates due to diarrhoea in infants: the 2006 Brazilian National Demographic Health Survey
}

Tulio Konstantyner*1,2, Thais Cláudia Roma de Oliveira Konstantyner ${ }^{3}$, Laís amaral Mais², Sarah Warkentin², José Augusto de Aguiar Carrazedo Taddei ${ }^{2}$

${ }^{1}$ Department of Health Sciences, University of Santo Amaro (UNISA), Sao Paulo, Brazil

${ }^{2}$ Department of Pediatrics, Federal University of Sao Paulo (UNIFESP), Sao Paulo, Brazil

${ }^{3}$ Faculty of Public Health, University of Sao Paulo (FSP/USP), Sao Paulo, Brazil

Received: August 23, 2015

DOI: $10.5430 /$ jer.v2n1p29
Accepted: September 22, $2015 \quad$ Online Published: September 30, 2015

URL: http://dx.doi.org/10.5430/jer.v2n1p29

\begin{abstract}
Aim: The aim of this study was to estimate the prevalence of and hospitalization rate due to diarrhea and to identify factors associated with diarrheal disease and related hospitalizations in children less than two years old in Brazil.

Methods: This was a cross-sectional study of 1,902 children who were participants in the 2006 National Demographic and Health Survey (Pesquisa Nacional de Demografia e Saúde da Criança e da Mulher - PNDS 2006). To collect data, children's mothers were interviewed. The prevalence of and hospitalization rate due to diarrhea were calculated for the two weeks before the interview and for the last year, respectively. Logistic regression models were fitted to identify the prevalence of diarrhea and the risk factors associated with diarrhea occurrence and related hospitalizations. A complex sample statistical technique was applied for all analyses.

Results: The prevalence of diarrhea and hospitalization rate due to diarrhea were $11.9 \%$ and $2.6 \%$, respectively. Children living in the North and Northeast regions had a greater risk of diarrhea, while children under 12 months old, those who were receiving age-appropriate exclusive breastfeeding and those with mothers greater than 35 years old were protected against the disease. Male children living in households that did not have a land-floor in the North and Northeast regions had a higher risk of hospitalization due to diarrhea, while children of mothers who had a higher education level ( $>4$ years) were protected against it.

Conclusion: Diarrhea is still a public health problem for children under two years old in Brazil, especially in the North and Northeast regions. Diarrhea control and prevention programs should inform young mothers with lower education levels about children's healthcare, including the benefits of breastfeeding.
\end{abstract}

Key Words: Diarrhea, Prevalence, Hospitalization, Risk factors, Public health

\section{INTRODUCTION}

Diarrhea is a frequent cause of morbidity among children and remains an important factor leading to Avoidable Paediatric Hospitalisations in developing countries. Such disease has been considered a public health concern because of the related costs of second and third level health care and the suffering of children. ${ }^{[1,2]}$ Multifaceted risk factors for diarrhea, such as the nutritional, environmental, socioeconomic, and

\footnotetext{
* Correspondence: Tulio Konstantyner; Email: tkmed@uol.com.br; Address: Department of Pediatrics, Universidade Federal de São Paulo (UNIFESP/EPM), Sao Paulo, Brazil.
} 
cultural aspects that are found in these areas, provide settings favorable for the occurrence of the disease. ${ }^{[3]}$ Diarrhea is defined as the passing of at least three loose or watery stools or one bloody loose stool within the last 24 hours. ${ }^{[4]}$ It is caused by different enteropathogens, mainly bacteria, viruses, protozoa, and helminths. Common outcomes are dehydration and malnutrition, which hinder weight and height gain in children, and affect intellect development in infants. ${ }^{[5-7]}$

Recent research has estimated that more than 2.5 billion cases of diarrhea occur annually among children under five, especially in the first two years of life, and of the 10 million children that die each year, approximately 1.5 million die due to diarrhea. ${ }^{[4,8]}$ Gastroenteritis, like diarrhea, is one of the most frequent causes of hospitalization in children under the age of nine. This disease has been more prominent in areas where the concentration of poverty is greater and the socioeconomic status is predominantly poor, due to the poor health, lack of access to primary healthcare services, inadequate life conditions and lack of sanitation experienced in these settings. ${ }^{[8,9]}$ However, the etiological agents and risk factors for diarrhea vary depending on the location, which makes knowledge of these aspects essential to developing prevention and control programs. ${ }^{[7]}$

Studies evaluating the prevalence of childhood diarrhea frequently analyze samples from children under five years of age. ${ }^{[10-12]}$ However, children under two are more vulnerable to gastrointestinal infections, ${ }^{[2,13-15]}$ because they have a maturing immune system and because of specific conditions related to physical growth and neuropsychomotor development that result in a physiological vulnerability to illness. ${ }^{[16,17]}$ Therefore, early childhood is the most opportune time to intervene and prevent long-term consequences of poor health outcomes, such as diarrhea and hospitalization. ${ }^{[18]}$

In Brazil, the Diarrhea Disease Monitoring Program (Programa de Monitorização das Doenças Diarreicas - MDDA) records the number of diarrhea episodes, and the Hospital Information System (Sistema de Informação Hospitalar SIH-SUS) registers the number of hospitalizations due to diarrheal disease. Information on the causes of hospitalization is commonly used as a measure of primary health care effectiveness and can be seen as a marker of its quality and availability, especially in developing countries like Brazil. ${ }^{[9]}$ However, there are some difficulties in the collection of this information. Input of data into the MDDA database, for example, depends on patients to seek care at a health service center and on the awareness of health professionals to report cases. The SIH-SUS is selective and only includes data from the public system and from private systems hired by the National Health System (Sistema Único de Saúde - SUS). ${ }^{[19]}$
On the other hand, population surveys are an important source of information on a population's health conditions, as continuous epidemiologic surveillance often does not exist or needs to be supplemented, as is the case for diarrhea in children. Data from these studies help to inform the formulation of health policies and action strategies, in addition to allowing national and international comparisons. ${ }^{[20]}$ In Brazil, the 2006 National Demographic and Health Survey (Pesquisa Nacional de Demografia e Saúde da Criança e da Mulher - PNDS 2006) is the most recent nationally representative household survey; such a survey is conducted every ten years and each includes questions related to diarrhea in children, among others diseases. ${ }^{[21]}$

The aim of this study was to estimate the prevalence of and hospitalization rate due to diarrhea, in addition to identifying factors associated with diarrheal disease and related hospitalizations, in children under two years of age who participated in the PNDS 2006.

\section{MethodS}

The present study used free access data from the PNDS $2006,{ }^{[21]}$ which aimed to describe the demographic profiles of Brazilian women of childbearing age and their children under five years of age in the five Brazilian macro-regions through the collection of a broad set of demographic, socioeconomic, cultural and health data, including the occurrence of diarrhea. ${ }^{[22]}$

Approximately 15,000 women between 15 and 49 years of age, who were the mothers of 5,000 children under five years of age, were interviewed during the months of November 2006 and March 2007. A probabilistic sampling process representing the five Brazilian macro-regions and the rural/urban type household distribution was used. Homes were selected from ten sample strata derived from the combination of macro-regions and household types. Within each stratum, two steps were followed: (1) selection of primary units, the census tracts, and (2) selection of secondary units, the household units. ${ }^{[23]}$

The initial population consisted of 1,902 children under two years of age with mothers between 15 and 49 years old. In the descriptive analyses, of the 1902 children, four $(0.2 \%)$ were excluded due to missing information about the outcomes (diarrhea prevalence and related hospitalizations). In the multivariate analysis of the prevalence of diarrhea, 316 children $(16.6 \%)$ were excluded because of a lack of data on the variables that composed the final model (whether receiving age-appropriate exclusive breastfeeding and source of drinking water). In the multivariate analysis of the hospitalization rate due to diarrhea, 40 children $(2.1 \%)$ were 
excluded due to a lack of data on the variables that composed the final model (maternal education, source of drinking water, and type of house floor).

The occurrence of diarrhea in the two weeks before the interview and hospitalizations due to the disease for the last 12 months were investigated. Information for all children was provided by the mothers, and it was up to the mothers to determine whether there had been a case of diarrhea and/or a hospitalization due to the disease. Socioeconomic, environmental and demographic characteristics were described as follows: (a) characteristics related to the child: age $(<$ 12 months or 12-23 months), sex (male or female), whether they were receiving age-appropriate exclusive breastfeeding (until 6 months), and nutritional index [z score of height for age (HAZ), weight for age (WAZ), and weight for height (WHZ)]; ${ }^{[24]}$ (b) characteristics related to the mother: age (1519 years, 20-34 years, or $\geq 35$ years), education $(<4$ years or $\geq 4$ years), and number of children (including the studied child); (c) characteristics related to the household: Brazilian macro-region, household situation (urban or rural), density (number of people in the house divided by the number of rooms used to sleep), existence of a bathroom in the house, type of floor, source of drinking water, and per capita family income (<US\$ 93.00 or $\geq$ US\$ 93.00). Particularly, we considered a child living below poverty line when the per capita family income was less than US\$ 3.00 per day (US\$ 93.00 per month) according to Brazilian minimum wage quoted in 2006. ${ }^{[25]}$

A descriptive analysis of the percentage distributions of the studied variables among the children was performed. The prevalences of diarrhea in the two weeks before the interview and of hospitalization due to the disease in the last year were estimated, considering at least one episode per child; the factors associated with diarrheal prevalence and related hospitalizations were identified. The selection criterion for the explanatory included in the logistic model required an association corresponding to a $p<.20$ in the bivariate analyses. Control variables were included in the final model because of the biological plausibility of determination of Diarrhea (source of drinking water) or the demographic importance (sex and household situation) according to previous studies. ${ }^{[13,14,26,28]}$ A maximum level of $p=.05$ was chosen to indicate a significant association, and variables found to have a significant association under this criterion were retained in the final model. The Hosmer-Lemeshow test was used to verify the final logistic model's fit. ${ }^{[29]}$

The Stata statistical software package version 12.0 was used to analyze the data and to expand the sample for all estimates by using the module "svy", which allowed considering all aspects of the complex sampling design of the PNDS 2006 and, consequently, providing national representativeness. ${ }^{[30]}$

The present study is part of a research project regarding the nutrition of Brazilian children under two years of age, which has been approved by the Ethics Committee of the Federal University of Sao Paulo (UNIFESP).

\section{Results}

Children were distributed homogeneously among all age groups, and the proportion of gender was similar. Only 5.4\% of children were being exclusively and age-appropriately breastfed at the time of the interview. Based on the three evaluated nutritional indexes, less than $9.0 \%$ of the children had any nutritional deficit. Most of the children had mothers aged between 20 and 34 years $(71.0 \%)$ with more than four years of education $(82.4 \%)$ and with less than three children (82.9\%). Regarding the household situation, $37.6 \%$ of households were in the North and Northeast regions. Most of the houses were in an urban area and were characterized as having one bathroom, a not land-floor, and a density of three or more rooms used to sleep. Concerning the family income, two thirds of families studied earned less than US\$ 93.00 per capita (see Table 1).

According to the cases reported by the mothers, the estimated prevalence of diarrhea in the two weeks before the interview was $11.9 \%$ (CI [95\%]: 9.4\%-14.4\%). The factors associated with the occurrence of diarrhea are shown in Table 2. In the multivariate analyses, "density" and "per capita family income" were associated with macro-region and, when simultaneously included in the model, they canceled each other statistically. Macro-region was retained in the final model because it had a high statistical significance and smaller percentage of missing data. "Child's sex", "household situation" and "source of drinking water" remained in the final model, so estimates were adjusted for these variables. The multivariate logistic regression showed a greater risk of diarrhea among children from the North and Northeast regions (OR = $1.7 ; p=.047)$ compared to those from other Brazilian macroregions. Conversely, children younger than 12 months of age $(\mathrm{OR}=0.5 ; p=.001)$, those receiving age-appropriate exclusive breastfeeding $(\mathrm{OR}=0.2 ; p=.016)$, and those with mothers at least 35 years old $(\mathrm{OR}=0.4 ; p=.031)$ were more protected from the occurrence of diarrhea.

According to the cases reported by the mothers, the hospitalization rate due to diarrhea in the 12 months prior to the interviews was $2.6 \%$ (CI [95\%]: 1.6\%-3.6\%). Factors associated with hospitalizations related to diarrhea are presented in Table 3. The variables "existence of bathroom in the house", 
Table 1. Distribution of children's, mothers', and households' characteristics among children under two years of age. Brazil, PNDS - 2006

\begin{tabular}{|c|c|c|c|c|c|}
\hline Variable & 0 & & Variable & & \\
\hline Children's characteristics & & & Households' characteristics & & \\
\hline Age (months) ${ }^{*}$ & & & Macro-region ${ }^{*}$ & & \\
\hline$<12$ & 53.4 & $49.4-57.4$ & North & 10.3 & $8.7-11.8$ \\
\hline $12-23$ & 46.6 & $42.6-50.6$ & Northeast & 27.3 & $22.8-31.7$ \\
\hline Sex ${ }^{*}$ & & & Midwest & 8.2 & $7.0-9.5$ \\
\hline Female & 47.5 & $43.0-51.9$ & South & 12.2 & $10.2-14.3$ \\
\hline Male & 52.5 & $48.1-57.0$ & Southeast & 42.0 & $36.6-47.3$ \\
\hline $\begin{array}{l}\text { Receiving age-appropriate exclusive } \\
\text { breastfeeding }(n=1,582)\end{array}$ & & & Situation ${ }^{*}$ & & \\
\hline No & 94.6 & $92.8-96.4$ & Urban & 82.2 & $78.3-86.0$ \\
\hline Yes & 5.4 & $3.5-7.2$ & Rural & 17.8 & $14.0-21.7$ \\
\hline HAZ ${ }^{*}$ & & & Per capita family income (US\$)* & & \\
\hline$\geq-2$ & 91.4 & $88.6-94.2$ & $>93.00$ & 33.5 & $28.5-38.5$ \\
\hline$<-2$ & 8.6 & $5.7-11.4$ & $\leq 93.00$ & 66.5 & $61.5-71.5$ \\
\hline WAZ* & & & Density ${ }^{*}$ & & \\
\hline$\geq-2$ & 97.0 & $95.7-98.3$ & $<3$ & 45.8 & $40.8-50.9$ \\
\hline$<-2$ & 3.0 & $1.7-4.3$ & $\geq 3$ & 54.2 & $49.1-59.2$ \\
\hline $\mathrm{WHZ}^{*}$ & & & $\begin{array}{l}\text { Existence of bathroom in the } \\
\text { house }^{*}\end{array}$ & & \\
\hline$\geq-2$ & 96.5 & $95.0-98.0$ & No & 7.8 & $5.4-10.0$ \\
\hline$<-2$ & 3.5 & $2.0-5.0$ & Yes & 92.2 & $89.9-94.5$ \\
\hline Mothers' characteristics & & & Type of floor $(n=1,869)$ & & \\
\hline Age (years) ${ }^{*}$ & & & Land & 3.8 & $2.1-5.4$ \\
\hline 15 a 19 & 18.6 & $14.8-22.3$ & Other floors & 96.2 & $94.6-97.8$ \\
\hline 20 a 34 & 71.0 & $67.1-75.0$ & Source of drinking water $(n=1,893)$ & & \\
\hline$\geq 35$ & 10.4 & $8.2-12.6$ & Not treated & 33.4 & $29.3-37.6$ \\
\hline Education (years) $(n=1,891)$ & & & Treated & 66.6 & $62.4-70.7$ \\
\hline$\leq 4$ & 17.6 & $14.3-21.0$ & & & \\
\hline$>4$ & 82.4 & $79.0-85.7$ & & & \\
\hline Number of children ${ }^{*}$ & & & & & \\
\hline$<3$ & 82.8 & $80.2-85.5$ & & & \\
\hline$\geq 3$ & 17.2 & $14.5-19.8$ & & & \\
\hline
\end{tabular}

Note. $\mathrm{CI}=$ confidence interval; $\mathrm{HAZ}=\mathrm{z}$ score of height for age; $\mathrm{WAZ}=\mathrm{z}$ score of weight for age; $\mathrm{WHZ}=\mathrm{z}$ score of weight for height; quoted in $2006: \mathrm{US} \$ 1.00=\mathrm{R} \$ 2.15$ (Brazilian currency). ${ }^{*} \mathrm{n}=1,898$.

"number of children", and "malnutrition (WAZ)" lost their variate model, so estimates were adjusted for these variables. statistical significance when inserted in the multivariate The multivariate logistic regression indicated a great risk of model, so these variables were removed. "Household situa- hospitalization due to diarrhea in male children ( $\mathrm{OR}=2.4 ; p$ tion" and "source of drinking water" remained in the multi- $=.030)$, children living in a house with a not land-floor $(\mathrm{OR}=$ 
$6.7 ; p=.049$ ), and children living in the North and Northeast or more years of education was a protective factor against $(\mathrm{OR}=4.5 ; p=.001)$ compared to those from other Brazil- hospitalizations due to diarrhea $(\mathrm{OR}=0.4 ; p=.021)$. ian macro-regions. In addition, having a mother with four

Table 2. Diarrhea prevalence and bivariate and multivariate analyses of factors associated with occurrence of diarrhea in children under two years old. Brazil, PNDS - 2006

\begin{tabular}{|c|c|c|c|c|c|c|c|}
\hline \multirow{2}{*}{ Variables } & \multirow{2}{*}{\begin{tabular}{l|}
$\mathbf{P}$ \\
$\%$
\end{tabular}} & \multicolumn{3}{|c|}{ Bivariate analyses * } & \multicolumn{3}{|c|}{ Multivariate analyses ${ }^{* *}$} \\
\hline & & OR & $\mathbf{C I}_{95 \%}$ & $p$ & OR & $\mathbf{C I}{ }_{95 \%}$ & $p$ \\
\hline \multicolumn{8}{|c|}{ Demographic and nutritional characteristics } \\
\hline \multicolumn{8}{|c|}{ Child's age (months) } \\
\hline $12-23$ & 16.5 & 1 & & & 1 & & \\
\hline$<12$ & 7.9 & 0.4 & $0.3-0.7$ & .001 & 0.5 & $0.3-0.9$ & .015 \\
\hline \multicolumn{8}{|l|}{ Child's sex } \\
\hline Female & 11.1 & 1 & & & 1 & & \\
\hline Male & 12.6 & 1.1 & $0.7-1.8$ & .533 & 1.1 & $0.7-1.8$ & .700 \\
\hline \multicolumn{8}{|c|}{ Receiving age-appropriate exclusive breastfeeding } \\
\hline No & 12.8 & 1 & & & 1 & & \\
\hline Yes & 2.4 & 0.2 & $0.1-0.5$ & .001 & 0.2 & $0.1-0.8$ & .016 \\
\hline \multicolumn{8}{|l|}{$H A Z$} \\
\hline$\geq-2$ & 12.2 & 1 & & & - & & \\
\hline$<-2$ & 14 & 1.2 & $0.6-2.4$ & .666 & - & - & - \\
\hline \multicolumn{8}{|l|}{ Mothers' characteristics } \\
\hline \multicolumn{8}{|l|}{ Age (years) } \\
\hline $15-19$ & 13.4 & 1.1 & $0.6-1.8$ & .783 & 1.1 & $0.6-1.8$ & .850 \\
\hline $20-34$ & 12.6 & 1 & & & 1 & & \\
\hline$\geq 35$ & 0.4 & 0.3 & $0.1-0.8$ & .004 & 0.4 & $0.1-0.9$ & .031 \\
\hline \multicolumn{8}{|l|}{ Education (years) } \\
\hline$\leq 4$ & 13.6 & 1 & & & - & & \\
\hline$>4$ & 11.5 & 0.8 & $0.5-1.4$ & .473 & - & - & - \\
\hline \multicolumn{8}{|l|}{ Households' characteristics } \\
\hline \multicolumn{8}{|l|}{ Macro-region } \\
\hline Midwest, South, Southeast & 9.6 & 1 & & & 1 & & \\
\hline North, Northeast & 15.7 & 1.7 & $1.1-2.8$ & .023 & 1.7 & $1.0-2.9$ & .047 \\
\hline \multicolumn{8}{|l|}{ Situation } \\
\hline Urban & 11.5 & 1 & & & 1 & & \\
\hline Rural & 13.5 & 1.2 & $0.7-2.0$ & .498 & 1 & $0.6-1.6$ & .898 \\
\hline \multicolumn{8}{|c|}{ Per capita family income (US\$) } \\
\hline$>93.00$ & 7.7 & 1 & & & - & & \\
\hline$\leq 93.00$ & 14.8 & 2.1 & $1.1-3.8$ & .018 & - & - & - \\
\hline \multicolumn{8}{|l|}{ Density } \\
\hline$<3$ & 9 & 1 & & & - & & \\
\hline$\geq 3$ & 14.3 & 1.7 & $1.1-2.7$ & .028 & - & - & - \\
\hline \multicolumn{8}{|c|}{ Existence of bathroom in the house } \\
\hline No & 18.1 & 1 & & & - & & \\
\hline Yes & 11.4 & 0.6 & $0.3-1.1$ & .108 & - & - & - \\
\hline \multicolumn{8}{|l|}{ Source of drinking water } \\
\hline Not treated & 12.1 & 1 & & & 1 & & \\
\hline Treated & 11.8 & 1 & $0.6-1.5$ & .887 & 1.2 & $0.7-2.0$ & .476 \\
\hline
\end{tabular}

Note. $\mathrm{P}=$ prevalence of diarrhea in the two weeks before the interview; $\mathrm{OR}=$ odds ratio; $\mathrm{CI}=$ confidence interval; $\mathrm{HAZ}=\mathrm{z}$ score of height for age; quoted in 2006 : US $\$ 1.00=\mathrm{R} \$ 2.15$ (Brazilian currency " $\mathrm{n}=1,898$; selected variables for the multivariate analyses. ${ }^{* *} \mathrm{n}=1,582$ 
Table 3. Diarrhea hospitalization rate and bivariate and multivariate analyses of factors associated with diarrheal hospitalizations in the last 12 months in children under two years old. Brazil, PNDS - 2006

\begin{tabular}{|c|c|c|c|c|c|c|c|}
\hline \multirow{2}{*}{ Variables } & \multirow{2}{*}{$\begin{array}{l}\mathrm{T} \\
\%\end{array}$} & \multicolumn{3}{|c|}{ Bivariate analyses ${ }^{*}$} & \multicolumn{3}{|c|}{ Multivariate analyses ${ }^{* *}$} \\
\hline & & OR & IC $_{95 \%}$ & $p$ & OR & IC $_{95 \%}$ & $p$ \\
\hline \multicolumn{8}{|c|}{ Demographic and nutritional characteristics } \\
\hline \multicolumn{8}{|c|}{ Child's sex } \\
\hline Female & 1.4 & 1 & & & 1 & & \\
\hline Male & 3.7 & 2.6 & $1.2-5.9$ & .018 & 2.4 & $1.1-5.5$ & .030 \\
\hline \multicolumn{8}{|l|}{$H A Z$} \\
\hline$\geq-2$ & 3 & 1 & & & - & & \\
\hline$<-2$ & 3.5 & 1.3 & $0.4-3.8$ & 622 & - & - & - \\
\hline \multicolumn{8}{|l|}{ Mothers' characteristics } \\
\hline \multicolumn{8}{|l|}{ Age (years) } \\
\hline $15-19$ & 3.7 & 1.5 & $0.6-3.3$ & .352 & - & - & - \\
\hline $20-34$ & 2.6 & 1 & & & - & & \\
\hline$\geq 35$ & 0.1 & 4.7 & $0.1-1.8$ & .163 & - & - & - \\
\hline \multicolumn{8}{|l|}{ Education (years) } \\
\hline$\leq 4$ & 0.5 & 1 & & & 1 & & \\
\hline$>4$ & 0.2 & 0.3 & $0.1-0.7$ & .004 & 0.4 & $0.2-0.9$ & .021 \\
\hline \multicolumn{8}{|l|}{ Number of children } \\
\hline$<3$ & 2.3 & 1 & & & - & & \\
\hline$\geq 3$ & 4 & 1.8 & $0.9-3.6$ & .109 & - & - & - \\
\hline \multicolumn{8}{|l|}{ Households' characteristics } \\
\hline \multicolumn{8}{|l|}{ Macro-region } \\
\hline Midwest, South, Southeast & 1.1 & 1 & & & 1 & & \\
\hline North, Northeast & 5.2 & 5.1 & $2.2-12.0$ & $<.001$ & 4.5 & $1.9-10.8$ & .001 \\
\hline \multicolumn{8}{|l|}{ Situation } \\
\hline Urban & 2.3 & 1 & & & 1 & & \\
\hline Rural & 3.9 & 1.7 & $0.7-3.9$ & .211 & 1.2 & $0.4-3.1$ & .759 \\
\hline \multicolumn{8}{|c|}{ Existence of bathroom in the house } \\
\hline No & 6 & 1 & & & - & & \\
\hline Yes & 2.3 & 0.4 & $0.1-0.9$ & .038 & - & - & - \\
\hline \multicolumn{8}{|l|}{ Type of floor } \\
\hline Land & 0.9 & 1 & & & 1 & & \\
\hline Other floors & 2.7 & 3.2 & $0.6-18.1$ & .194 & 6.7 & $1.1-44.9$ & .049 \\
\hline \multicolumn{8}{|l|}{ Source of drinking water } \\
\hline Not treated & 3.3 & 1 & & & 1 & & \\
\hline Treated & 2.2 & 0.7 & $0.3-1.4$ & .308 & 0.7 & $0.3-1.6$ & .426 \\
\hline
\end{tabular}

Note. $\mathrm{T}=$ hospitalization rate for diarrhea in the 12 months prior to the interview; $\mathrm{OR}=$ odds ratio; $\mathrm{CI}=$ confidence interval; $\mathrm{HAZ}=\mathrm{z}$ score of height for age. ${ }^{*} \mathrm{n}=1,898$; selected variables for the multivariate analyses.

${ }^{* * *} \mathrm{n}=1,858$

\section{Discussion}

The results of this study indicated that $11.9 \%$ of children younger than 24 months of age had diarrhea in the two weeks before the interview. Only 4 factors were independently and significantly associated with the diarrhea occurrence: macro- region of residence, children age, receiving age-appropriate exclusive breastfeeding and maternal age.

Only $2.6 \%$ of children were hospitalized due to diarrhea in the 12 months prior to the interviews. We found 4 factors 
associated with these hospitalizations: gender, type of house floor, macro-region of residence and maternal education.

Diarrheal disease is the second leading cause of death in children under five years old, even if it is both preventable and treatable. Each year, an estimated 2.5 billion cases of diarrhea occur among children under five years of age, leading to approximately 760,000 deaths. This overall incidence has remained relatively stable over the past two decades. ${ }^{[2,15]}$

Most cases occurs in poor and developing areas, mainly Africa and South Asia, where bouts of diarrhoea are more likely to result in death or other severe outcomes. The incidence of diarrheal diseases varies greatly with the seasons and a child's age. The youngest children are most vulnerable: Incidence is highest in the first two years of life and declines as a child grows older. ${ }^{[15]}$

According, the estimated prevalence of diarrhea in the present study was higher than the prevalence in children younger than five that was demonstrated in the PNDS 2006 report $(9.4 \%){ }^{[26]}$ These findings support the idea that the younger age group is more susceptible to gastrointestinal infectious diseases, an idea which is presented in the literature..$^{[4,15]}$ Nevertheless, children younger than 12 months are more dependent on adult care, require feeding appropriate for their age, and tend to be less exposed to infectious agents and environmental risk factors, especially if they are being breastfed. ${ }^{[31]}$ This may justify the finding that the children in the first year of life in this study experienced a lower occurrence of diarrhea compared to those in the second year of life.

Children living in the North and Northeast had a greater risk for the occurrence of diarrhea and for hospitalization due to diarrhea when compared to children living in other macroregions. Bühler et al. (2014) found the risk of infant death to be five times greater in children living in the North and Northeast than in those living in the South. The authors argue that the insufficient coverage of health units in areas with the worst living conditions hinder access to hospital care for these children, leading to deaths. ${ }^{[5]}$ Despite the creation of many health policies and the implementation of measures to control and prevent morbidity among children at national level, such as the Family Health Care Strategy (Estratégia Saúde da Família - ESF) and the National Program to Encourage Breastfeeding (Programa Nacional de Incentivo ao Aleitamento Materno - PNIAM), persistent inequalities, especially those related to wealth distribution, quality of life, social conditions, and sanitation, may still constitute important determinants of children's morbidity and mortality. ${ }^{[32]}$ This is particularly true for the occurrence of diarrhea in children younger than two years of age.
The present study showed that children who received exclusive breastfeeding during the first semester of life were more protected against the occurrence of diarrhea. The protective effect of breast milk against infectious diseases might be displayed by this result; this effect occurs not only due to breast milk's direct anti-infective action via the presence of secretory immunoglobulin-A in human milk but also due to all of breast milk's advantages in infant feeding. ${ }^{[33]}$ Together, both benefits of breast milk contribute to children's health, especially by decreasing the occurrence of diseases with multifactorial causes like diarrhea. ${ }^{[4,31,34]}$ However, this research did not analyze breastfeeding during the two weeks before the data were gathered or the duration of age-appropriate exclusive breastfeeding due to the lack of information about quantity and frequency of breastfeeding, the adequacy of which differs according to age. These limitations may have hampered the discovery of further evidence regarding the protective effects of breastfeeding against diarrhea.

Regarding maternal characteristics, having a mother at least 35 years old was found to be a protective factor against diarrhea. Other studies about childhood diarrhea also showed that younger women are more likely to expose a child to risk factors for diarrhea, which is a consequence of the difficulty of recognizing the risk factors for this disease. Additionally, this association may be explained by the improvement in childcare that accompanies advanced age due to previous experiences. ${ }^{[27,35,36]}$

Hospitalizations due to diarrhea should be rare because this is a self-limiting and easily handled disease. Simple care, such as oral rehydration therapy (ORT), is efficient in preventing worsening of cases and, consequently, in preventing a need for hospitalization. ${ }^{[37]}$ However, the present study found a rate of hospitalizations due to diarrhea of $2.6 \%$ in the year prior to the interview, a similar finding of persistence of avoidable hospitalizations due to this disease which was showed in other studies of the same nature. ${ }^{[10,19]}$

Male children were more likely to be hospitalized due to diarrhea. According to Boccolini et al. (2012), boys tend to have more health problems in childhood, to remain hospitalized longer, to have a higher prevalence of prematurity, and to be weaned earlier than girls in Brazil. ${ }^{[31,38]}$ However, there is evidence that the association between sex and disease determinants is mediated by a variety of factors that include culture, birth order, number of boys and girls in the family, and parental decisions regarding the allocation of available resources, which shows that sex may be only one component in a complex system of influences. ${ }^{[39]}$

On the other hand, children of mothers with more than four years of education experienced a lower risk of hospitaliza- 
tion due to diarrhea. It is already known that higher parental educational levels have great importance in the prevention and control of morbidity among children. More specifically, the enhanced possibility to encounter and understand health promotion information as a result of education decreases the risk of infectious and nutritional diseases in children of educated parents. ${ }^{[4,40,41]}$ Higher educational levels are also associated with improved toilet facilities in both rural and urban settings, which means better access to sanitation and hygiene in the household. ${ }^{[42]}$

Living in the North and Northeast was also a risk factor associated with hospitalizations for diarrhea, in addition to being a risk factor for the prevalence of the disease in the two weeks before the interview. Regarding hospitalizations for diarrhea, the household situation seems to be a reflection of failure in the management of the disease, which may result in severe cases of diarrhea that require hospital care. This situation may have multifactorial causes, which result in factors such as the caregiver's insensitivity to the severity of a case, the difficulty in access to primary care, and the lack of training of health professionals in providing adequate assistance. ${ }^{[27]}$

Children who lived in houses with floors that were not land experienced a higher risk for hospitalization due to diarrhea than children who lived in land-floor houses. Regarding housing conditions, this finding is the opposite of results commonly reported in the literature. ${ }^{[8,14]}$ However, a possible explanation for this finding is that the risk situation represents an indicator of available hospital services and facilities, assuming that not land-floor houses frequently translate to more structured housing and, thus, are closer to hospital care. Therefore, even if there was inadequate treatment in the case of diarrhea, it is possible that children whose caregivers had better access to healthcare were hospitalized.

Rotavirus was the main pathogen associated with the occurrence of diarrhea before the introduction of a rotavirus vaccine in childhood immunization programs. This vaccine has led to a decline in hospitalizations caused by diarrhea and in mortality rates in low-and middle-income countries. ${ }^{[8,43,44]}$ In Brazil, this vaccine was incorporated in the National Immunization Program in April 2006, with two recommended doses at two and four months of age. It is important to highlight that the data gathering in this survey occurred in this same year, so it is probable that the majority of the children in the sample were not vaccinated at the time of the interview, which limits the ability to compare disease occurrence and hospitalization rates with figures from recent research.

Although population surveys are an important source of information about a population's health, some limitations should be considered when making inferences based on the pre- sented results. It should be noted that there was a possible influence of companies' and services' financial interests on the observed hospitalization rate due to diarrhea, as the remuneration and transfer of public and private funds in the system is based on care production (number of cases treated by the service provider). This potential influence was not evaluated in our study.

It is important to clarify that the data gathering of PNDS 2006 was performed between November and March, when there is a higher prevalence of diarrhea cases. Therefore, the high occurrence of these cases in the two weeks before the interview may be a result of this seasonal effect and may reflect the peak diarrhea occurrence in children under two years of age. Additionally, this survey did not investigate the etiology of the diarrhea cases, which may compromise the quality and interpretation of the data.

All the information related to children in this study was provided by the mothers, and it was up to the mothers to determine whether there was a case of diarrhea and/or a hospitalization due to the disease, which may have compromised the data's precision. Additionally, the mother defined whether the child had diarrhea, and this interpretation could be biased because a mother's lack of knowledge could lead her to overestimate the occurrence of diarrhea by judging a single episode of watery stools to be diarrhea. The data may also be subject to recall bias, due to the characteristics of the outcomes and the study's retrospective nature.

The hospitalization rate in this study may be underestimated because this household survey analyzed only children that survived and did not account for the cases where the child was hospitalized and died in the 12 months before the interview. Beyond that, the analysis of diarrhea hospitalization was potentially impaired as children less than 12 months have not been followed for a year, decreasing time of a possible hospitalization.

It is also important to highlight the missing data, which resulted from refusals to answer or from operational problems in the data gathering and may compromise the results when there are significant differences between the characteristics of respondents and non-respondents. ${ }^{[20]}$ However, the sample size lost, derived from the lack of information about the variables used in the multivariate analyses, was minimal and should not compromise the interpretation of the results.

For the estimation of population parameters in the present study, an adequate statistical treatment was used for the sample design, and information showed that the possible mistakes associated with sampling were considered, which guarantees the data's validity and reproducibility. ${ }^{[28]}$ 
Despite the limitations of using data obtained in population surveys, the PNDS 2006 is the most recent research at the national level that considers aspects related to childhood diarrhea. The methodology of the present study was performed to provide a comprehensive view of the epidemiological characteristics of the diarrhea in Brazilian children under two years old. Therefore, the results showed a unique and valid estimation of prevalence and factors associated with occurrence and hospitalization due to infant diarrhea.

\section{Conclusion}

Diarrhea is still an important public health issue in children younger than two years of age in Brazil. The results confirmed the vulnerability of children living in the North and
Northeast regarding the occurrence of diarrhea and hospitalizations due to diarrhea. In addition, the reported risk factors reinforce the importance of implementing programs for prevention and control of this infection in infancy; these programs should include the provision of information to young mothers with low education levels and poor life conditions regarding their children's health care, including the advantages of breastfeeding. Finally, given the relevance of maternal characteristics (age and education), we recommend that qualitative studies approaching the parental knowledge of the need and the importance to have their children protected against diarrhea should be performed to evidence the characteristics susceptible to health interventions.

\section{REFERENCES}

[1] Chang CF, Herrod HG, Steinberg SS. Prevalence and costs of acute and chronic potentially avoidable pediatric hospitalizations in Tennessee. Tenn Med. 2009; 102(11): 35-9. PMid:19943422.

[2] Boschi-Pinto C, Lanata CF, Black RE. The global burden of childhood diarrhea. In: Ehiri JE, Meremikwu M. International Maternal and Child Health. 2009; 225-43.

[3] Guimarães ZA, Costa MC, Paim JS, et al. Declínio e desigualdades sociais na mortalidade infantil por diarreia. Revista da Sociedade Brasileira de Medicina Tropical. 2001; 34: 473-8. http: //dx.doi.org/10.1590/S0037-86822001000500011

[4] Bahartha AS, AlEzzi JI. Risk factors of diarrhea in children under 5 years in Al-Mukalla, Yemen. Saudi Medical Journal. 2015; 36: 720-4. http://dx.doi.org/10.15537/smj . 2015.6.11266

[5] Buhler HF, Ignotti E, Neves SMAS, et al. Análise espacial de indicadores integrados determinantes da mortalidade por diarreia aguda em crianças menores de 1 ano em regiões geográficas. Ciência e Saúde Coletiva. 2014; 19: 4131-40. http://dx.doi.org/10.15 90/1413-812320141910.09282014

[6] Kvestad I, Taneja S, Hysing M, et al. Diarrhea, stimulation and growth predict neurodevelopment in young North Indian children. PLoS ONE. 2015; 10: e0121743. http://dx.doi.org/10.1371 /journal.pone.0121743

[7] Nhampossa T, Mandomando I, Acacio S, et al. Diarrheal disease in rural Mozambique: burden, risk factors and etiology of diarrheal disease among children aged 0-59 months seeking care at health facilities. PLoS ONE. 2015; 10: 1-19. http://dx.doi.org/10. 1371/journal . pone.0119824

[8] Ichihara MYT, Rodrigues LC, Santos CAST, et al. Risk factors for hospital admission of Brazilian children with non-rotavirus diarrhoea: a case control-study. Transctions of the Royal Society of Tropical Medicine and Hygiene. 2015; 109: 454-61. http: //dx.doi.org/10.1093/trstmh/trv041

[9] Rodrigues-Bastos RM, Campos EMS, Ribeiro LC, et al. Hospitalizations for primary care-sensitive conditions in a Southern Brazilian municipality. Revista da Associação Médica Brasileira. 2013; 59: 120-7. http://dx.doi .org/10.1016/j.ramb. 2012.11.001

[10] Kale PL, Fernandes C, Nobre FF. Padrão temporal das internações e óbitos por diarreia em crianças, 1995 a 1998, Rio de Janeiro. Revista de Saúde Pública. 2004; 38: 30-7. http://dx.doi.org/10.1590 /S0034-89102004000100005

[11] Parashar UD, Bresee JS, Glass RI. The global burden of diarrheal disease in children. Bulletin of the World Health Organization. 2003; 81: 236.

[12] Rasella D, Aquino R, Barreto ML. Reducing childhood mortality from diarrhea and lower respiratory tract infections in Brazil. Pediatrics. 2010; 126: e534-40. http://dx.doi.org/10.1542/peds . 2009-3197

[13] Lins MGM, Silva GAP. Doença diarreica em crianças hospitalizadas - importância da diarreia persistente. Jornal de Pediatria. 2000; 76 : 37-43. PMid:14647699.

[14] Vanderlei LCM, Silva GAP, Braga JU. Fatores de risco para internamento por diarreia aguda em menores de dois anos: estudo de caso-controle. Cadernos de Saúde Pública. 2003; 19: 455-63. http://dx.doi.org/10.1590/S0102-311X2003000200012

[15] World Health Organization. Diarrhea: Why children are still dying and what can be done. WHO Library Cataloging-in-Publication Data. 2009.

[16] Chen L, Lu HM, Shih SF, et al. Poverty related risk for potentially preventable hospitalisations among children in Taiwan. BMC Health Services Research. 2010; 10: 196. http://dx. doi.org/10.1186 /1472-6963-10-196

[17] Granzotto JA, Fonseca SS, Steffen MS, et al. Fatores relacionados à internação pediátrica em um hospital universitário da Região Sul do Brasil. Pediatria. 2010; 32: 15-9. http://dx.doi.org/10.1186 /1472-6963-10-196

[18] Butler DC, Thurecht L, Brown L, et al. Social exclusion, deprivation and child health: a spatial analysis of ambulatory care sensitive conditions in children aged 0-4 years in Victoria, Australia. Social Science and Medicine. 2013; 94: 9-16. http://dx.doi.org/10. 1016/j. socscimed. 2013.06.029

[19] Oliveira TCR, Latorre MRDO. Tendências da internação e da mortalidade infantil por diarreia: Brasil, 1995 a 2005. Revista de Saúde Pública. 2010; 44: 102-11. http://dx.doi.org/10.1590/S0034 $-89102010000100011$

[20] Viacava F. Informações em saúde: a importância dos inquéritos populacionais. Ciência e Saúde Coletiva. 2002; 7: 607-21. http: //dx.doi.org/10.1590/S1413-81232002000400002

Published by Sciedu Press 
[21] Ministério da Saúde do Brasil. Pesquisa Nacional de Demografia e Saúde da Criança e da Mulher - PNDS 2006: dimensões do processo reprodutivo e da saúde da criança. 2009. http: //bvsms . saude.go v.br/bvs/publicacoes/pnds_crianca_mulher.pdf

[22] Ministério da Saúde do Brasil. Pesquisa Nacional de Demografia e Saúde da Criança e da Mulher - PNDS 2006: banco de dados. 2009 http://bvsms.saude.gov.br/bvs/pnds/banco_dados.php

[23] Cavenaghi S. Aspectos metodológicos e comparabilidade com pesquisas anteriores. In: Ministério da Saúde do Brasil. Pesquisa Nacional de Demografia e Saúde da Criança e da Mulher - PNDS 2006: dimensões do processo reprodutivo e da saúde da criança. 2009; 14-32.

[24] World Health Organization. WHO Child Growth Standards: Length/height-for-age, Weight-for-age, Weight-for-length, Weightfor-height and Body mass index-for-age: Methods and Development. 2006.

[25] Ministério do Trabalho do Brasil. Salário Mínimo - Guia Trabalhista - Portal Brasil. Available from: http: //www.portalbrasil.net /salariominimo.htm

[26] Cunha EMGP, Barison EM. Saúde das crianças. In: Ministério da Saúde do Brasil. Pesquisa Nacional de Demografia e Saúde da Criança e da Mulher - PNDS 2006: dimensões do processo reprodutivo e da saúde da criança. 2009; 172-94.

[27] Fuchs SC, Victora CG. Risk and prognostic factors for diarrheal disease in Brazilian infants: A special case-control design application. Cadernos de Saúde Pública. 2002; 18: 773-82. http: //dx.doi.org/10.1590/S0102-311X2002000300026

[28] Szwarcwald CL, Damacena GN. Amostras complexas em inquéritos populacionais: planejamento e implicações na análise estatística dos dados. Revista Brasileira de Epidemiologia. 2008; 11: 38-45 http://dx.doi.org/10.1590/S1415-790X2008000500004

[29] Kleinbaum DG, Kupper LL, Muller KE, et al. Applied regression analysis and other multivariable methods. 2008.

[30] StataCorp. Stata Statistical Software - Release 12. 2011.

[31] Boccolini CS, Boccolini PMM, Carvalho ML, et al. Padrões de aleitamento materno exclusivo e internação por diarréia entre 1999 e 2008 em capitais brasileiras. Ciência e Saúde Coletiva. 2012; 17: 1857-63 http://dx.doi.org/10.1590/S1413-81232012000700025

[32] Silva LMV, Costa MCN, Paim JSP, et al. Brechas redutíveis de mortalidade em capitais brasileiras (1980-1998). Epidemiologia e Serviços de Saúde. 2005; 14: 203-22. http://dx.doi.org/10.51 23/S1679-49742005000400002
[33] American Academy of Pediatrics. Section on breastfeeding: breastfeeding and the use of human milk. Pediatrics. 2005; 115: 2004-491. http://dx.doi.org/10.1542/peds.2011-3552

[34] Gribble KD. Mechanisms behind breastmilk's protection against, and artificial baby milk's facilitation of diarrhoeal illness. Breastfeeding Review Journal. 2011; 19: 19-26. PMid:22053500.

[35] Finlay JE, Özaltin E, Canning D. The association of maternal age with infant mortality, child anthropometric failure, diarrhea and anaemia for first birth: evidence from 55 low-and-middle-income countries. BMJ Open. 2011; 1: e000226. http://dx.doi.org/10.1136/b mjopen-2011-000226

[36] Diouf K, Tabatabai P, Rudolph J, et al. Diarrhoea prevalence in children under five years of age in rural Burundi: an assessment of social and behavioural factors at the household level. Global Health Action. 2014; 7: 24895. http://dx.doi.org/10.3402/gha.v7.24895

[37] Victora CG, Bryce J, Fontaine O, et al. Reducing deaths from diarrhea through oral rehydration therapy. Bulletin of the World Health Organization. 2000; 78: 1246-55. PMid:11100619.

[38] Gissler M, Järvelin MR, Louhiala P, et al. Boys have more health problems in childhood than girls: follow-up of the 1987 Finnish birth cohort. Acta Paediatrica. 1999; 88: 310-4. PMid:10229043.

[39] Pande R. Selective gender differences in childhood nutrition and immunization in rural India: the role of siblings. Demography. 2003; 40: 395-418. PMid:12962055.

[40] Machado MM, Lindsay AC, Mota GM, et al. A community perspective on changes in health related to diarrhea in northeastern in Brazil. Food and Nutrition Bulletin. 2011; 32: 103-11. PMid:22164972.

[41] George CM, Perin J, Calani KJN, et al. Risk factors for diarrhea in children under five years of age residing in peri-urban communities in Cochabamba, Bolivia. The American Journal of Tropical Medicine and Hygiene. 2014; 91(6): 1190-6. http://dx.doi.org/10.42 69/ajtmh. 14-0057

[42] Colombara DV, Faruque AS, Cowgill KD, et al. Risk factors for diarrhea hospitalization in Bangladesh, 2000-2008: a case-case study of cholera and shigellosis. BMC Infectious Diseases. 2014; 14: 440. http://dx.doi.org/10.1186/1471-2334-14-440

[43] Fernandes EG, Sato HK, Leshem E, et al. Impact of rotavirus vaccination on diarrhea-related hospitalizations in São Paulo State, Brazil. Vaccine. 2014; 32(27): 3402-8. http://dx.doi.org/10.1016/j .vaccine. 2014.04 .015

[44] Ichihara MYT, Rodrigues LC, Santos CAST, et al. Effectiveness of rotavirus vaccine against hospitalized rotavirus diarrhea: A casecontrol study. Vaccine. 2014; 32: 2740-7. http://dx.doi.org/1 $0.1016 / j$. vaccine .2014 .01 .007 